\title{
ORGANISATIONAL CULTURE OF HOSPITALS TO PREDICT TURNOVER INTENTIONS OF PROFESSIONAL NURSES
}

\section{Dr E Jacobs}

D Com

Human Resource Practitioner, Sol Plaatjie Municipality, Private Bag X5030, Kimberley

Corresponding author: ejacobs@solplaatje.org.za

\section{Prof G Roodt \\ D Admin \\ Professor, Head of Centre of Work Performance and Departmental Research Unit, Department of Human Resource Management, University of Johannesburg}

Keywords: organisational culture; turnover intentions; professional nurses; general linear modelling; retention strategy

\begin{abstract}
The objective of this study was to determine if organisational culture predicts turnover intentions of professional nurses. A predictive model with organisational culture and various proposed mediating variables, namely knowledge sharing, organisational commitment, organisational citisenship behaviour and job satisfaction, as well as various demographic variables was developed to determine turnover intentions through applying General Linear Modelling. A correlational design with questionnaires was used. A sample of professional nurses $(N=530)$ in private and provincial hospitals was obtained. The results indicate that organisational culture has a significantly negative correlation with turnover intentions. Organisational culture also interacted with job satisfaction, knowledge sharing, and the white professional nurses' category to decrease turnover intentions and with Organisational Citisen Behaviours to increase turnover intentions in a final predictive model. It is therefore recommended that nursing employers seriously embark on strategies to improve the organisational culture to retain their talent.
\end{abstract}

\section{OPSOMMING}

Die doel van die studie was om te bepaal of organisasiekultuur arbeidsomset-voornemens van professionele verpleegkundiges voorspel. 'n Voorspellingsmodel met organisasiekultuur en verskeie voorgestelde tussenkomende veranderlikes, naamlik kennisdeling, organisasieverbintenis, organisasie-burgerskapsgedrag en werkstevredenheid, asook verskeie demografiese veranderlikes was ontwikkel deur Algemene Liniêre Modellering. 'n Korrelasie-ontwerp met behulp van vraelyste is gebruik. ' $n$ Steekproef van professionele verpleegkundiges $(N=530)$ in private en provinsiale hospitale is verkry. Die resultate toon dat organisasiekultuur betekenisvol negatief korrelleer met arbeidsomsetvoornemens. Organisasiekultuur het ook in interaksie met werkstevredenheid en kennisdeling, asook die kategorie blanke verpleegkundiges in ' $n$ finale model arbeidsomsetvoornemens verlaag en saam met organisasieburgerskapsgedrag arbeidsomsetvoornemens verhoog. Daar word aanbeveel dat werkgewers oorweging skenk aan intervensies wat die organisasiekultuur gunstiger maak om personeel te behou. 


\section{BACKGROUND AND PROBLEM STATE- MENT}

From various reports it is clear that the South African nursing profession is in a crisis. Professional nurses leave the country in search of lucrative work overseas and this exodus will have a catastrophic effect on the delivery of health care over the next decade (Brits, 2003:7; Derby, 2003:12). South Africa is one of the five most prominent suppliers of overseas registrations (Vujicic, Zurn, Diallo, Adams \& Dal Poz, 2004:2). These shortages of staff, due to the brain drain and turnover problems in hospitals, are also creating various other problems such as enormous pressure on existing employees (Jewkes, Abrahams \& Mvo, 1998:1785; Newman, Maylor \& Chansarkar, 2002:273; Smit, 2003:17) resulting in job stress and job dissatisfaction, as well as medico-legal incidents (Smit, 2003:17). Nurse-patient relationships are also at times characterised by conflict, clinical neglect, verbal and physical abuse (Jewkes et al. 1998:1781).

Financial constraints make it almost impossible to compete with remuneration offerings from national and international competitors to retain talent. Furthermore, current exchange rates make it very attractive for professional nurses to earn foreign money and tax-free salaries (Kockott, 2003:3). The existence of many job opportunities overseas (Smetherham \& Laurance, 2003:5), the influence of globalisation and the belief that a person's career is enriched with overseas experience, further contributes to making this problem almost uncontrollable for hospital employers.

This raises the question of whether employers should not rather focus their retention strategies on things they can control internally to retain their employees. An approach to build strategies around the needs and work circumstances of professional nurses, rather than only focusing of financial incentives, was adopted in this research.

\section{THE PURPOSE OF THIS STUDY}

The main purpose of the research was to develop a predictive model of turnover intentions by entering the independent variable (organisational culture) and the proposed mediating variables (knowledge sharing, organisational commitment, organisational citisenship behavior, job satisfaction) as well as various demographic variables into an equation to determine which variables independently and/or interactively emerged to predict turnover intentions. These mentioned variables were selected on the grounds of their respective relationship with, or impact on, organisational culture and turnover intentions. This paper focuses on an important part of this objective; it discusses the role of organisational culture, as well as the interaction with the mediating and demographic variables, in predicting turnover intentions of professional nurses.

More precisely the empirical objectives of this paper can be stated as:

- to determine the relationship between organisational culture and turnover intentions on a bivariate level.

- to determine the amount of variance organisational culture accounted for independently and interactively when entering all the selected variables in a predictive model of turnover intentions on a multi-variate level.

\section{LITERATURE OVERVIEW}

\section{Organisational Culture}

Organisational culture has been defined in many ways by various authors and researchers. However, many would agree that organisational culture refers to a set of values, beliefs and behaviour patterns that form the core identity of organisations; and these help in shaping the employees' behaviour (Erwee, Lynch, Millet, Smith \& Roodt, 2001:7; Van der Post, de Coning \& Smit, 1997:147).

According to Van der Post et al. (1997:148) the study of organisational culture can be approached by identifying certain dimensions that shape behaviour and eventually can be regarded as the culture of the organisation. The advantage of this approach is that the model provides an organisational analysis that perceives culture as a feature of the organisation that can be studied and manipulated in isolation (Erwee et al. 2001:8). The dimensions are the following: conflict resolution, culture management, customer orientation, disposition towards change, employee participation, goal clarity, human resource orientation, identification with the organisation, locus of authority, management 
style, organisational focus, organisational integration, performance orientation, reward orientation and task structure. Organisational culture, for the purpose of this study, was defined as: "... a system of shared meaning, the prevailing background fabric of prescriptions and proscriptions for behaviour, the system of beliefs and values that ultimately shape organisational behaviour (Van der Post et al. 1997:147)."

\section{Turnover Intentions}

Sager, Griffeth and Hom (1998:255) referred to turnover cognitions as mental decisions intervening between an individual's attitude regarding the job, and decision to leave or stay. According to Elangovan (2001:162), intention to leave represents an attitudinal orientation or a cognitive manifestation of the behavioural decision to leave.

The theory of planned behaviour (Ajzen, 1991:179), suggested that behavioural intention is a good predictor of actual behaviour. It has been successfully demonstrated in previous studies that behavioural intention to leave is consistently correlated with turnover (Fox \& Fallon, 2003:3). There is considerable support for the notion that intention to leave is probably the most important and immediate antecedent of turnover decisions (Fox \& Fallon, 2003:3; Slate \& Vogel, 1997:402). Shields and Ward (2001:692) reported that quitting intentions were the strongest predictor of actual turnover, with $79 \%$ of nurses in a longitudinal study reporting an intention to leave and did so within one year. Steel and Ovalle (1984:673) reported in a large number of studies between 1965 and 1983, a correlation coefficient of 0.50 between quitting intentions and actual turnover.

Some commentators would postulate that the notion of commitment to either job or profession is a more useful concept than turnover cognitions. However, research indicates that turnover cognitions have a distinct conceptual base and significant explanatory power (Carbery, Garavan, O'Brien \& McDonnell, 2003:649). Lambert, Hogan and Barton (2001:236) suggested that more attention should be given to the direct and indirect influences of variables on intention to leave as opposed to the actual act of turnover. From the employer's point of view, intention to leave may be a more important variable then the actual act of turnover. If the precur- sors of intention to quit are better understood, the employer could possibly institute changes to affect this intention. However, once an employee has left, there is little the employer can do except the expense of hire and train another employee.

\section{The relationship between organisational culture and turnover intentions}

A review of the literature reveals a limitation in research regarding the relationship between organisational culture and turnover intentions. However, it is widely reported, although not empirically yet determined, that organisational culture in hospitals can contribute towards lower turnover (Coile, 2001:224). Coile (2001:226) reported that hospitals with lower turnover clearly indicated a more positive organisational culture than the others. Culture within these hospitals had a strong mission, empowerment of leaders, participative management, patient focus, reward orientation (for improvement), visible/accessible leaders and supported education. Tepeci and Bartlett (2002:163) found that the perceived culture explained $39 \%$ of the variance in intent to leave in a sample of 182 students in the hospitality industry.

Petkoon and Roodt (2004:46) were of the opinion that South Africa's success in the global economy will be positively or negatively affected by the ability of individual companies and industries to adapt their cultures to fit the global challenges. One of these challenges is certainly the retention of professional people in a global economy. While culture is not the only determinant of business success or failure, it can have a competitive advantage in the retention of top-quality staff (Sadri \& Lees, 2002:11).

An extensive literature research yielded no results of the concept of organisational culture in South African hospitals. Related concepts, such as lack of staff support and absence of proper incentives were reported (Hall, 2004:28). Both these concepts are seen by Van der Post et al. (1997:150) as dimensions of organisational culture, namely the management style and reward orientation. The caring profession in parts of the South African public health services are characterised by conflict (Jewkes et al. 1998:1781). Van der Post et al. (1997:149) saw conflict resolution as an important dimension of organisational culture. 
Furthermore, the severe staff shortages threaten service capability and the quality of patient care (Newman et al. 2002:273; Smetherham \& Laurance, 2003:5). Once again, Van der Post et al. (1997:149) regarded customer orientation as an important dimension of organisational culture. It is therefore clear that although related aspects of organisational culture were reported in South African hospitals, the concept was not theoretically and empirically investigated and reported.

\section{Knowledge sharing, organisational commitment, organisational citisenship behavior and job satisfaction}

Knowledge sharing, organisational commitment, organisational citisenship behaviours (OCB's) and job satisfaction are distinct concepts from organisational culture. These concepts were included in the study to determine whether they interact with organisational culture in predicting turnover intentions. To date, most of the studies concentrated on job satisfaction and organisational commitment as antecedents for turnover intentions and indicated significant relationships (DeConinck \& Stilwell, 2004:229). These concepts are very important and need further investigation, specifically with the current scenario of professional nurses in South Africa. It was also suggested in this study, that two other organisational processes need investigation. These are knowledge sharing behaviour and organisational citisenship behaviours. These have been selected as it believed that they will fulfil professional nurses' higher order needs as described by the work of Maslow (1954).

A short description of each concept is provided as the emphasis of this paper is on organisational culture and turnover intentions.

Knowledge sharing occurs when an individual is willing to assist as well as learn from others in the development of new competencies. To "learn" means to "digest", to "absorb", and to "apply" (Salopek \& Dixon, 2002:63). Ryu, Hee Ho and Han (2003:113) emphasised that knowledge sharing is a people-to-people process. For the purpose of this study knowledge sharing was defined as "... a willingness..." (Chua, 2003:117; Hislop, 2003:184) "... on the part of those workers who possess knowledge to share and communicate it..." (Hislop, 2003:184), "...to teach others, to develop new competencies and participating in any organisational activity like training or any other programme to enhance knowledge..." (Yang \& Wan, 2004:62)"... to ultimately create value..." (Sveiby in Wagner, Cassimjee \& Nel, 2002:50).

Mowday (1999:389) described organisational commitment as the attachment that is formed between employees and their employing organisation. Roodt (1997:7) proposed measuring commitment by distinguishing between different commitment foci. An understanding of the different foci can probably explain the dynamics of employee commitment in the work context. According to Roodt (2004a:85) a golden thread running through all the definitions of commitment is the potential of a particular focus to satisfy salient needs. Roodt (2004a:85) therefore proposed a motivational approach to define and measure commitment and describes it as "... a cognitive predisposition towards a particular focus, insofar this focus has the potential to satisfy needs, realise values and achieve goals."

Organisational citisenship behaviours (OCB's) are employee work behaviours such as helping others, staying late, or working weekends, performing at levels that exceed enforceable standards, tolerating impositions or inconveniences on the job, and being actively involved in company affairs (Podsakoff, Mackenzie, Paine \& Bachrach, 2000:516). Organ (1988:4) defined organisational citisenship behaviour as: "....individual behaviour that is discretionary, not directly or explicitly recognised by the formal reward system, and that in the aggregate promotes the effective functioning of the organisation". "Discretionary" means that the behaviour is not an enforceable requirement of the role or the job description, that is, the clearly specifiable terms of the person's employment contract with the organisation. The behaviour is rather a matter of personal choice, so that its omission is not generally understood as punishable.

Job satisfaction refers to a worker's general attitude towards his or her job. Weiss, Dawis, England and Lofquist (1967) cited in Cook, Hepworth, Wall and Warr (1981:21) identified various extrinsic factors (for example, supervision, compensation, company policies and practices) and intrinsic factors (for example, activity, variety, responsibility) as potential sources of satisfaction or dissatisfaction. The intrinsic factors are 
thought to measure satisfaction with intrinsic reinforcement factors. The extrinsic factors are external to the job. Job satisfaction is therefore, for the purpose of this study, defined as "... The degree people achieve and maintain correspondence with the environment satisfying both extrinsic and intrinsic needs (Weiss et al. 1967 cited in Cook et al. 1981:21)."

\section{METHOD}

\section{Research design}

The research questions were investigated (tested) by making use of a correlational design. The conceptualisation or mode for reasoning to choose a correlational design was first to test hypotheses and secondly to analyse variables to propose a theoretical model.

\section{Sample}

The target population was professional nurses working in hospitals. The requirements were that these nurses should be regarded as professional and registered as such. Staf- or assistant nurses were not included in the target population. Various important challenges and problems had to be addressed to determine the sampling frame and unit of analysis. According to figures by the South African Nursing Council (in 2004), there were approximately 93000 registered professional nurses in South Africa. (This figure must not be confused with the estimated 155400 if staff nurses are also taken in consideration). Professional nurses are employed in different sectors (for example, hospitals, municipalities, academic institutions and other industries). However, hospitals are the most important employers of professional nurses (Green, 2003:3). It was therefore decided to only include professional hospital nurses.

The next step was to select which hospitals to include in the sampling frame. It was decided to include five private hospitals and four provincial hospitals in the Free State, Northern Cape and North West Provinces of South Africa in the sampling frame. The motivation for this was based on the assumption that different types of hospitals (private and provincial) in different provinces and surroundings (urban and rural) will probably have different organisational cultures that will yield a sample with diverse characteristics.
The next step was to decide on the actual composition of the unit of analysis (more or less 1100 professional nurses work in the selected hospitals). Although the target population was determined by the set criteria as explained; it was decided to make use of a nonprobability sample at each of the selected hospitals. A non-probability sample in this sense refers to all professional nurses who were available to complete the questionnaire at a specific point in time (normally a two day period) in each hospital.

The respondents were not randomly selected. All who met the criteria and were available were included. Such an approach is regarded as less scientific, but more economical in terms of time and money (Welman \& Kruger, 1999:62). The limitations compared to systematic or stratified sampling methods are acknowledged. However, Kerlinger (1986) defends the use of non-probability samples by noting that it may lack the virtues of random sampling, but are often necessary and unavoidable. Their weakness can to some extent be mitigated by using knowledge, expertise, and care in selecting samples as was the case in this study. It seemed practically and ethically correct to utilise a convenience sample as employers were reluctant to allow time off to complete the questionnaires due to staff shortages and the complex shift system that determine working hours for professional nurses, as well as the research procedure to personally visit hospitals to ensure a high response rate of questionnaires.

The final sample consists of 530 respondents in the selected hospitals (more or less $50 \%$ ). This resulted in a sample with diverse characteristics regarding race, age, home language, number of dependents, level of seniority, qualifications, tenure in hospital and profession, working in different units and gender (Table 1). According to Huysamen (in Welman \& Kruger, 1999:64) it is not necessary to draw a sample size bigger than 500 because it has little effect in decreasing the standard error of measurement.

Table 1 shows that all the different categories of subgroups were well represented. The only demographic variable discarded for further analysis was gender as nurses were predominantly female (95\%). 
Table 1: Demographics of sample of professional nurses $(\mathrm{N}=530)$

\begin{tabular}{|c|c|c|c|c|c|c|c|c|}
\hline Type of hospital & & & Race* $^{*}$ & & & Gender & & \\
\hline Private & 368 & $69 \%$ & African & 195 & $37 \%$ & Male & 26 & $5 \%$ \\
\hline \multirow[t]{2}{*}{ Government } & 162 & $31 \%$ & White & 265 & $50 \%$ & Female & 504 & $95 \%$ \\
\hline & & & Coloured & 67 & $13 \%$ & & & \\
\hline $\mathrm{Age}^{\star}$ & & & Unit & & & $\begin{array}{l}\text { Tenure in } \\
\text { hospital }\end{array}$ & & \\
\hline Younger 30 years & 88 & $17 \%$ & ICU/Casualties & 181 & $34 \%$ & $\begin{array}{l}\text { Not a year } \\
\text { completed }\end{array}$ & 87 & $16 \%$ \\
\hline $30-39$ years & 188 & $35 \%$ & Paed/Maternity & 94 & $18 \%$ & $1-5$ years & 173 & $33 \%$ \\
\hline 40-49 years & 161 & $30 \%$ & Surgery/Theatre & 111 & $21 \%$ & $6-10$ years & 160 & $30 \%$ \\
\hline 50 years and older & 92 & $18 \%$ & General & 144 & $27 \%$ & $\begin{array}{l}11 \text { years and } \\
\text { more }\end{array}$ & 110 & $21 \%$ \\
\hline $\begin{array}{l}\text { Completed years in } \\
\text { unit }\end{array}$ & & & Highest Qualification & & & Home language $^{\star}$ & & \\
\hline Less than 1 & 115 & $22 \%$ & Nursing diploma & 220 & $42 \%$ & Afrikaans & 308 & $58 \%$ \\
\hline $1-5$ years & 241 & $45 \%$ & Post nursing diploma & 193 & $36 \%$ & $\begin{array}{l}\text { Other (English } \\
\text { included) }\end{array}$ & 92 & $18 \%$ \\
\hline 6 years and longer & 174 & $33 \%$ & $\begin{array}{l}\text { Nursing degree or post } \\
\text { qualification }\end{array}$ & 117 & $22 \%$ & African language & 129 & $24 \%$ \\
\hline $\begin{array}{l}\text { Years completed in } \\
\text { profession }\end{array}$ & & & Dependents under 18 & & & $\begin{array}{l}\text { Dependents } \\
\text { above } 18\end{array}$ & & \\
\hline 5 years and less & 99 & $19 \%$ & None & 163 & $31 \%$ & None & 198 & $37 \%$ \\
\hline $6-10$ years & 97 & $18 \%$ & One & 105 & $20 \%$ & One & 158 & $30 \%$ \\
\hline $11-20$ years & 183 & $35 \%$ & Two & 164 & $31 \%$ & Two & 84 & $16 \%$ \\
\hline 20 years and more & 151 & $28 \%$ & Three or more & 98 & $18 \%$ & Three or more & 90 & $17 \%$ \\
\hline Rank & & & Marital status & & & & & \\
\hline Professional nurse & 294 & $56 \%$ & Not married & 140 & $26 \%$ & & & \\
\hline $\begin{array}{l}\text { Senior professional } \\
\text { nurse }\end{array}$ & 65 & $12 \%$ & Married & 295 & $56 \%$ & & & \\
\hline Chief/Unit manager & 171 & $32 \%$ & Divorced & 95 & $18 \%$ & & & \\
\hline
\end{tabular}

* missing responses recorded

\section{Measuring instruments}

The Organisational Culture Survey (OCS) (97 items) was used to measure fifteen dimensions of organisational culture. The OCS is based on a model of organisational analysis that perceives culture as a feature of the organisation that can be studied and manipulated in isolation (Erwee et al. 2001:8). This questionnaire was selected because it seems to contain the dimensions that can influence the nurse's perception of the organisation. It was developed in South Africa by Van der Post et al. (1997:147-168) and a Cronbach Alpha of 0.991 was obtained in a study by Erwee et al. (2001:9) indicating high reliability. A Cronbach Alpha of 0,70 or higher is considered acceptable (Cortina, 1993:98). It therefore was an appropriate instrument to measure organisational culture. A deviation from the original questionnaire was followed as each item was 
measured on a seven-point intensity response scale anchored at extreme poles. The items were changed from statements to questions. An example is: "How aware are employees of the objectives in this organisation?" ("Not aware at all" 1-low intensity, to "Always aware" 7-high intensity). By using this questionnaire, the individual work unit's culture, the individual hospital's culture and the overall organisational culture could be determined.

Turnover intentions were measured by a questionnaire developed by Roodt (2004b:1). The questionnaire consists of 14 items that were measured on a sevenpoint intensity response scale anchored at extreme poles (e.g. "never" 1-low intensity, to "always" 7-high intensity). Examples of items included in this questionnaire (Roodt, 2004b:1) were: "How often have you recently considered leaving your job?" and "How frequently have you been scanning news papers for new job opportunities?" A Cronbach Alpha of 0.913 was obtained in this study indicating an acceptable reliability. The turnover literature lacks formally validated scales to represent turnover cognitions (Sager et al. 1998:259). The motivation to develop this questionnaire is that most instruments in the literature measure turnover intentions on only a relatively small number of items. Various researchers have used only one item (Guimaraes, 1997:46). The approach to use single-item indicators to measure turnover cognitions is criticised as construct validity in unknown (Sager et al. 1998:259). Only a few studies could be found where more than three items per instrument were used (Fox \& Fallon, 2003:3). The questionnaire is attached as it is a new development (Annexure A).

A literature study was conducted to compile a questionnaire as no suitable measure for knowledge sharing was found. The questionnaire consists of 23 items, each with a five-point intensity response scale anchored at extreme poles ranging from "to no extent" or "disagree" (low intensity) to "to a large extent" or "agree" (high intensity). The questionnaire consists of six sections representing different domains of knowledge sharing, namely why knowledge is shared in the organisation (for example, to get recognition -5 questions), opportunities for knowledge sharing (for example, to attend training courses -3 questions), the contribution of knowledge sharing to the organisation (for example, competitiveness -3 questions), why others readily share knowledge (for example, that trust exists -6 questions), why one would not readily share knowledge [for example, career would be in danger -3 questions (-)], and why others do not readily share knowledge [for example, colleagues don't want to do likewise -3 questions(-)]. A Cronbach Alpha of 0.839 was obtained for the Knowledge Sharing Questionnaire. The questionnaire is attached as it is a new development (Annexure B).

The Organisational Commitment Questionnaire developed by Roodt (1997:8) was used to measure commitment. The questionnaire was suitable for this investigation as it can be regarded as a motivational approach to study commitment. The questionnaire consists of 38 items, each with a five-point intensity response scale anchored at extreme poles. The foci of the questionnaire consist of work, career, occupation and organisation. An example of an item is: "How much time and energy do you willingly devote to work?" ("no time" 1-low intensity to "all of my time" 5-high intensity). A Cronbach Alpha of 0.926 was obtained for the Organisational Commitment Questionnaire.

Organisational citisenship behaviour was assessed by the Van Dyne and LePine (1998:108-120) seven-item "helping" scale. The items were originally adapted from Organ and Konovsky (1989:160). Four additional items of the original altruism scales from the work of Smith, Organ and Near (1983:653-663) were also included in the questionnaire. Voice was measured by a 6-item scale as used by Van Dyne and LePine (1998:108120). A deviation from the original helping questionnaire was followed as each item was measured on a sevenpoint intensity response scale anchored at extreme poles ("never" 1-low intensity, to "always" 7-high intensity). An example of an item for the helping questionnaire was: "How often do you volunteer to do things for this work group?" and for the voice questionnaire: "How frequently do you make recommendations concerning issues that affect your work group?" Self ratings were used. A Cronbach Alpha of 0.923 was obtained for the Organisational Citisenship Questionnaire.

Job satisfaction was assessed by the Minnesota Satisfaction Questionnaire ((Weiss et al. 1967 cited in Cook et al. 1981:21). The MSQ20 measures 20 different items and can be categorised into extrinsic and intrinsic satisfaction. The questionnaire measures the 
following satisfaction domains: activity, independence, variety, social status, moral values, security, social service, authority, ability utilisation, responsibility, creativity, achievement (intrinsic), supervision-human relations, supervision-technical, company policies and practices, compensation, advancement, working conditions, co-workers and recognition (extrinsic). Questions are measured on a five-point scale and will make use of an intensity scale with 1-low intensity (for example, never) and 5-high intensity (for example, always). An example is: "What are the chances for advancement in your present job? (1-no chance; 5-high chance). A Cronbach Alpha of 0.886 was obtained for the MSQ.

Each questionnaire was factor analysed according to the procedure suggested by Schepers (2004:31) in order to determine the factor structure of the instrument. One of the advantages of this method is to minimise artefactors (Schepers, 1992:1). This procedure includes first and second level factor analysis. Factors were postulated according to Kaiser's (1970) criterion (eigenvalues-greater-than-unity) and extracted by means of Principal Axis Factoring. Sub-scores were calculated on the obtained factors and they were subsequently intercorrelated.

\section{Procedure}

Permission to do the research was obtained from the Regional Director of the private hospitals and the Director: Knowledge Management of the provincial hospitals. Aletter of consent was provided by the Ethics Research Committee of the Faculty Ethics Committee of the University of Johannesburg.

Questionnaires were completed in venues outside the units, such as training centres, to prevent interruptions. The purpose of the questionnaire was explained shortly by the researcher and each respondent completed the questionnaire personally. The main reason for this approach was to ensure that all items were completed, time was saved for employees, confidentiality was improved and a quick response was promoted. All questionnaires were handled anonymously. Questionnaires were only available in English. Although many respondents indicated that their home language is Afrikaans or an African language, no problems were reported as everyone was proficient in English. A pilot study was conducted in two rounds and the questionnaire was evaluated by the Statistical Consultation Service of the University of Johannesburg.

After completion of the questionnaires, a thorough procedure to clean the data was followed. A questionnaire was discarded if there were missing responses. A number of 570 questionnaires were distributed. A final number of 530 questionnaires were usable and 40 rejected. After this, the data was captured and processed by STATCON (Statistical Consultation Services at the University of Johannesburg).

\section{Statistical analysis}

The first objective was to determine the relationship between organisational culture and turnover intentions. This was tested by the Pearson product-moment correlation (this hypothesis was further analysed by introducing General Linear Modelling).

The second objective, namely to determine the amount of variance organisational culture accounted for independently and interactively when entering all the selected variables in a predictive model of turnover intentions, was tested by applying General Linear Modelling. According to Kerlinger (1986) it is unrealistic, even wrong, to study and learn only an approach that is basically bivariate in conception. Multivariate methods are like the behavioural reality they try to reflect: complex and difficult to understand. Kerlinger continues by arguing that from all methods of analysis, multivariate methods are the most powerful and appropriate for scientific behavioural research. His argument basically rests on the idea that behavioural problems are almost all multivariate in nature and cannot be solved with a bivariate (two-variable) approach - that is, an approach that considers only one independent and one dependent variable at a time.

Broadly stated, the theory driving General Linear Modelling (GLM) seeks to identify those quantities in systems of equations which remain unchanged under linear transformations of the variables in the system. The General Linear Model differs from the multiple regression model in terms of the number of dependent variables that can be analysed. The General Linear Model goes a step beyond the multivariate regression model by allowing for linear transformations or linear combinations of multiple dependent variables. This 
extension gives the General Linear Model important advantages over the multivariate regression models, which are inherently univariate (single dependent variables) methods. One advantage is that multivariate tests of significance can be employed when responses on multiple dependent variables are correlated. Multivariate tests of significance of independent linear combinations of multiple dependent variables can also give insight into which dimensions of the response variables are, and are not, related to the predictor variables. Independent variables can be continuous (for example, dimensions of organisational culture) or categorised (for example, demographic variables).

General Linear Modelling is also useful to compile predictive models and develop theories (a focus of this study). A theory is a group of logical, related statements that are presented as an explanation of a phenomenon. A theory thus encompasses one or more hypotheses (Welman \& Kruger, 1999:11). Analysis of variance (ANOVA) is used to uncover the main and interaction effects of categorical independent variables (called "factors") on an interval dependent variable. A "main effect" is the direct effect of an independent variable on the dependent variable. An "interaction effect" is the joint effect of two or more independent variables on the dependent variable. In using General Linear Modelling (GLM), the most parsimonious model was determined by entering the independent, mediating variables and all the demographic variables into the equation with interactions. The technique can be seen as entering various carefully selected variables into the equation where only the "strongest will ultimately survive" to predict the outcome variable (turnover intentions in this study). The GLM follows a process by first entering the demographic variables into the equation, then the independent and mediating variables and finally all the variables simultaneously to determine independent and interactive effects. From this final model it would be possible to determine the independent and interactive role of the independent variable (organisational culture), the demographic variables (categorised variables) and the mediating variables (knowledge sharing, organisational commitment, OCB's and job satisfaction) in determining turnover intentions. Only the results applicable to organisational culture will be discussed next.

\section{RESULTS}

The first important result is that a significant negative relationship $(r=-0.521 ; p<0.01)$ between organisational culture and turnover intentions was found, meaning that the more positive professional nurses were about the culture of the hospital, the less inclined they were to turnover intentions. One should remember that turn-

Table 2: Intercorrelation matrix (Pearson Correlations) of the second order factors (new factors) of the different constructs

\begin{tabular}{|c|c|c|c|c|c|c|c|}
\hline & $\begin{array}{l}\text { B: } \\
\text { Organisational } \\
\text { Culture }\end{array}$ & $\begin{array}{l}\text { C:1 } \\
\text { Knowledge } \\
\text { sharing } \\
\text { Factor One }\end{array}$ & $\begin{array}{l}\text { C:2 } \\
\text { Knowledge } \\
\text { sharing } \\
\text { Factor Two }\end{array}$ & $\begin{array}{l}\text { D: } \\
\text { Org } \\
\text { Commitment }\end{array}$ & E: OCB & $\begin{array}{l}\text { F: } \\
\text { Job } \\
\text { satisfaction }\end{array}$ & $\begin{array}{l}\text { G: } \\
\text { Turnover } \\
\text { Intentions }\end{array}$ \\
\hline B & 1 & $0.588(* *)$ & $0.404(* *)$ & $0.551(* *)$ & $0.328(* *)$ & $0.688(* *)$ & $-0.521(* *)$ \\
\hline C1 & $\left.0.588^{(\star *}\right)$ & 1 & $0.387\left(^{* \star}\right)$ & $0.445(* \star)$ & $\left.0.310^{* *}\right)$ & $\left.0.5499^{\star \star}\right)$ & $-0.418\left(^{\star \star}\right)$ \\
\hline $\mathrm{C} 2$ & $0.404\left({ }^{\star \star}\right)$ & $\left.0.387^{(\star \star}\right)$ & 1 & $0.456(* \star)$ & $\left.0.448{ }^{(* *}\right)$ & $0.376(\star \star)$ & $-0.234(* \star)$ \\
\hline D & $0.551(* \star)$ & $0.445(* \star)$ & $0.456(* \star)$ & 1 & $\left.0.5499^{* \star}\right)$ & $\left.0.605^{(* *}\right)$ & $-0.402(* \star)$ \\
\hline$E$ & $0.328(* \star)$ & $\left.0.310^{* \star}\right)$ & $0.448(* \star)$ & $\left.0.5499^{\star \star}\right)$ & 1 & $\left.0.448{ }^{(\star \star}\right)$ & -0.060 \\
\hline$F$ & $\left.0.688^{(\star \star}\right)$ & $\left.0.549{ }^{* \star}\right)$ & $0.376\left(^{\star \star}\right)$ & $0.605(\star \star)$ & 0.448 (**) $^{*}$ & 1 & $-0.516\left(^{* \star}\right)$ \\
\hline G & $-0.521(* \star)$ & $-0.418(\star \star)$ & $-0.234(* \star)$ & $-0.402(* \star)$ & -0.060 & $-0.516\left(^{(\star}\right)$ & 1 \\
\hline
\end{tabular}


over intentions are the most important predictor to actual turnover. A significant positive correlation exists between organisational culture and knowledge sharing, organisational commitment, organisational citizenship behaviour and job satisfaction. The correlations between organisational culture and all the other variables appear in Table 2.
Secondly, in using General Linear Modeling (GLM), the most parsimonious model was chosen including all the variables with interactions, explaining almost $49 \%$ of the variance in turnover intentions. The coefficients are depicted in Table 3 . The results of the most parsimonious predictive model for turnover intentions yielded that the interaction between organisational cul-

Table 3: General linear modelling (GLM) for predicting turnover intentions

\begin{tabular}{|c|c|c|c|c|c|}
\hline \multicolumn{6}{|l|}{ Coefficients } \\
\hline & \multicolumn{2}{|c|}{$\begin{array}{l}\text { Unstandardized } \\
\text { Coefficients }\end{array}$} & \multirow{2}{*}{\begin{tabular}{|l|}
$\begin{array}{l}\text { Standardized } \\
\text { Coefficients }\end{array}$ \\
Beta
\end{tabular}} & \multirow{2}{*}{$\mathbf{T}$} & \multirow{2}{*}{ Sig. } \\
\hline & B & Std. Error & & & \\
\hline (Constant) & 7.182 & 0.307 & & 23.429 & 0.000 \\
\hline Organisational Culture*Job Satisfaction & -0.145 & 0.020 & -0.680 & -7.122 & 0.000 \\
\hline $\begin{array}{l}\text { Organisational Culture*Organisational Citizen } \\
\text { Behaviours }\end{array}$ & 0.102 & 0.013 & 0.632 & 7.811 & 0.000 \\
\hline Organisational Culture * Indicator - White & -0.106 & 0.024 & -0.155 & -4.387 & 0.000 \\
\hline Organisational Commitment $\left({ }^{\star \star \star}\right)$ & -0.510 & 0.103 & -0.211 & -4.942 & 0.000 \\
\hline Indicator - ICU/Casualties and 50+ years (Age) & -0.657 & 0.225 & -0.096 & -2.925 & 0.004 \\
\hline Organisational Culture*Knowledge Sharing 1 & -0.056 & 0.017 & -0.256 & -3.241 & 0.001 \\
\hline $\begin{array}{l}\text { Indicator - 1-5 years (Current Unit) and Chief } \\
\text { Nurse }\end{array}$ & 0.429 & 0.127 & 0.109 & 3.367 & 0.001 \\
\hline $\begin{array}{l}\text { Indicator }-11+\text { years (Current Hospital) and } \\
\text { None (Dependents }>18 \text { ) }\end{array}$ & 0.729 & 0.199 & 0.119 & 3.672 & 0.000 \\
\hline $\begin{array}{l}\text { Indicator - Married/Co-Habitating and None } \\
\text { (Dependents }>18 \text { ) }\end{array}$ & -0.319 & 0.115 & -0.091 & -2.785 & 0.006 \\
\hline $\begin{array}{l}\text { Indicator }-50+\text { years (Age) and None } \\
\text { (Dependents }<18 \text { ) }\end{array}$ & -0.491 & 0.160 & -0.104 & -3.078 & 0.002 \\
\hline Indicator - ICU/Casualties and Degree & -0.465 & 0.156 & -0.096 & -2.972 & 0.003 \\
\hline $\begin{array}{l}\text { Dependent Variable: Turnover Intentions THE * SIGN DENOT } \\
\begin{array}{ll}(+) & \text { Increasing turnover intentions } \\
(-) & \text { Decreasing turnover intentions }\end{array}\end{array}$ & DTES INTE & CTION & & & \\
\hline${ }^{* * *}$ only independent predictor & & & & & \\
\hline
\end{tabular}


ture and job satisfaction $(B=-0.145)$; the interaction between organisational culture and knowledge sharing $(B=-0.056)$ and the interaction between organisational culture and white professional nurses $(B=-0.106)$ decreased turnover intentions, while the interaction between organisational culture and organisational citizenship behaviour $(B=0.102)$ increased turnover intentions. A significant result was that organisational commitment emerged as the only independent predictor of turnover intentions in the final model (positive B coefficients increase turnover intentions and negative $\mathrm{B}$ coefficients decreases turnover intentions).

\section{DISCUSSION}

The result of this study indicated that a statistically significant negative relationship exists between organisational culture and turnover intentions. This finding also supports the view that organisational culture contributes to organisational success and outcomes (Martins \& Martins, 2002:58) and also lower turnover intentions (Coile, 2001:226). It seems that organisational culture contributes significantly in decreasing turnover intentions, emerging with knowledge sharing, job satisfaction and white professional nurses (as race category) as predictors of turnover intentions of professional nurses. This result contributed to a greater understanding of the importance of organisational culture in hospitals and amongst professional nurses. Since the importance of knowledge sharing was evident in the results obtained from this study, the responsibility of managers and human resource departments to create opportunities for learning and sharing, such as training and development interventions to meet growth and development needs, are extremely important.

As mentioned earlier, although the emphasis of this paper is not on organisational commitment, it emerged as the only independent predictor of turnover intentions (the only variable "strong enough" to predict turnover intentions on its own). This result supports previous research that organisational commitment predicts turnover intentions. (DeConinck \& Stilwell, 2004:229).

A surprising result is that the interaction between organisational culture and organisational citizenship behavior are related to increasing turnover intentions. $A$ possible explanation might be that professional nurses feel that being involved in OCB's increases their workload, and that this in turn leads to more work pressure and higher turnover intentions. This may especially be true if they perceive that teamwork is lacking or their efforts are not compensated for. As stated, although work responsibilities and OCB's are conceptually or theoretically distinct, this distinction may not prevail in practice. One should also keep in mind that the nursing profession entails helping behavior as a logical task characteristic of the profession. They may therefore not realise that they are involved in citizenship behavior. One also may speculate that self ratings on OCB's might have influenced this result in the sense that performance was evaluated and not OCB's.

Turnover intentions of nurses can be actively managed through the management of contextual variables such as organisational culture and commitment. Since limited availability of professional nurses is a world-wide phenomenon, it is highly recommended that turnover prevention strategies should not only focus on compensation factors, but on well-planned interventions by hospital and nursing employers in the short- and long term. The predictive model developed for turnover intentions can be regarded as an important tool for health and nursing administrators to plan talent retention strategies. Since this model focused primarily on internal components, possible strategies can be derived from this model to prevent turnover intentions. The practical value of this model is that it focused on controllable dimensions of organisational culture. Employers can plan interventions specifically, even if some results can only be achieved in the long term.

\section{RECOMMENDATIONS}

Organisational culture is a complex concept and simplistic models to explain organisational behaviour and effectiveness will not improve the understanding thereof. Erwee et al. (2001:11) suggestion for a more complex model of organisation culture, constructed from different systems or subsystems, which interact on different levels, is supported. It is recommended that more turnover models should be developed, especially with manageable variables. More emphasis should be placed on organisational cultures of hospitals to ensure that professional nurses see it as an employer of choice. It is also recommended that nursing employers perceive the organisational culture as manageable, not just 
something that it the natural outcome of "something not controllable".

The turnover model developed in this study furthermore only focused on internal dimensions and excluded external forces such as job opportunities, which theoretically were described as important in turnover cognitions. It is recommended to determine the effect of job opportunities available on the model.

\section{CONCLUSION}

It is surprising that organisational culture has not previously been viewed as an important antecedent of organisational outcomes in both South African hospitals and in the nursing profession alike. This study has contributed to a greater understanding of the importance of organisational culture in hospitals and amongst professional nurses.

In conclusion it is clear that organisational culture, in interaction with the selected variables of knowledge sharing, job satisfaction and OCB's, as well as organisational commitment as independent predictor and various demographic variables, interactively predict turnover intentions. This answers the objectives of this study, namely that a relationship between organisational culture and turnover intentions of professional nurses exists, and that organisational culture accounted interactively with knowledge sharing, job satisfaction, OCB's and white professional nurses to predict turnover intentions.

\section{REFERENCES}

AJZEN, I 1991: The theory of planned behaviour. Organizational Behavior and Human Decision Processes, 50(2):179-211. BRITS, E 2003: Te veel verpleërs land-uit, sê RGN. Burger, 2 July. CARBERY, R; GARAVAN, TN; O'BRIEN, F \& MCDONNELL, J 2003 : Predicting hotel managers' turnover cognitions. Journal of Managerial Psychology, 18(7):649-679.

CHUA, A 2003: Knowledge sharing: A game people play. Aslib Proceedings: New information perspectives, 55(3):117129.

COILE, RC 2001: Magnet hospitals use culture, not wages, to solve nursing shortage. Journal of Healthcare Management, 46(4):224-228.

COOK, JD; HEPWORTH, SJ; WALL, TD \& WARR, PB 1981: The experience of work. A compendium and review of 249 measures and their use. London: Academic Press.

CORTINA, JM 1993: What is coefficient Cronbach alpha? An examination of the theory and applications. Journal of Applied Psychology, 78(1):98-104.

DECONINCK, JB \& STILWELL, CD 2004: Incorporating organizational justice, role states, pay satisfaction and supervisor satisfaction in a model of turnover intentions. Journal of Business Research, 57(3): 225-231.

DERBY, R 2003: Netcare gets a R1,4-bn boost from the UK. Citizen, 13 September.

ELANGOVAN, AR 2001: Causal ordering of stress, satisfaction and commitment, and intention to quit: A structural equations analysis. Leadership and Organization Development Journal, 22(4):159-165.

ERWEE, R; LYNCH, B; MILLET, B; SMITH, D \& ROODT, G 2001: Cross cultural equivalence of the organisational culture survey in Australia. SA Journal of Industrial Psychology, 27(3):7-12. FOX, SR \& FALLON, BJ 2003: Modeling the effect of work/life balance on job satisfaction and turnover intentions. Symposia paper presented at the $5^{\text {th }}$ Australian Industrial and Organisational Psychology Conference, Melbourne, Australia.

GREEN, J 2003: Plan to make grass greener for SA nurses. Star, 6 May.

GUIMARAES, T 1997: Assessing employee turnover intentions before/after TQM. International Journal of Quality and Reliability Management, 14(1):46-63.

HALL, EJ 2004: Nursing attrition and the work environment in South African health facilities. Curationis, 27(4):28-36.

HISLOP, D 2003: Linking human resource management and knowledge management via commitment: A review and research agenda. Employee Relations, 25(2):182-202.

JEWKES, R; ABRAHAMS, N \& MVO, Z 1998: Why do nurses abuse patients? Reflections from South African obstetric services. Social Science \& Medicine, 47(11):1781-1795.

KAISER, HF 1970: A second-generation Little Jiffy. Psychometrika, 35(4):401-415.

KERLINGER, FN 1986: Foundations of Behavioural Research. Orlando Florida: Harcourt Brace Jovanovich College Publishers. KOCKOTT, F 2003: Government developing strategies to retain health professionals. Business Day, 21 January.

LAMBERT, EG; HOGAN, NL \& BARTON, SM 2001: The impact of job satisfaction on turnover intent: A test of a structural measurement model using a national sample of workers. Social Science Journal, 38(2):233-250.

MARTINS, E \& MARTINS, N 2002: An organisational culture model to promote creativity and innovation. SA Journal of Industrial Psychology, 28(4):58-65.

MASLOW, A 1954: Motivation and Personality. New York. Harper \& Row. 
MOWDAY, RT 1999: Reflections on the study and relevance of organizational commitment. Human Resource Management Review, 8(4):387-401.

NEWMAN, K; MAYLOR, U \& CHANSARKAR, B 2002: "The nurse satisfaction, service quality and nurse retention chain": Implications for management of recruitment and retention. Journal of Management in Medicine, 16(4):271-291.

ORGAN, DW 1988: Organizational citizenship behaviour: The good soldier syndrome. Lexington, MA: Lexington Books.

ORGAN, DW \& KONOVSKY, M 1989: Cognitive versus affective determinants of organizational citizenship behavior. Journal of Applied Psychology, 74(1):57-164.

PETKOON, L \& ROODT, G 2004: The discriminant validity of the culture assessment instrument: A comparison of company subcultures. SA Journal of Industrial Psychology, 30(1):46-54. PODSAKOFF, PM; MACKENZIE, SB; PAINE, JB \& BACHRACH, DG 2000: Organizational citizenship behaviours: A critical review of the theoretical and empirical literature and suggestions for further research. Journal of Management, 26(3):513-563.

ROODT, G 2004a: Concept redundancy and contamination in employee commitment research: Current problems and future directions. SA Journal of Industrial Psychology, 30(1):82-90. ROODT, G 2004b: Turnover Intentions. Unpublished Document. University of Johannesburg: Johannesburg.

ROODT, G 1997: Theoretical and empirical linkages between workrelated commitment foci. SA Journal of Industrial Psychology, 23(2):6-13.

RYU, S; HEE HO, S \& HAN, I 2003: Knowledge sharing behavior of physicians in hospitals. Expert Systems with applications, 25(1):113-122.

SADRI, G \& LEES, B 2002: A cultural competitive advantage. Human Resource Management International Digest, 10(3):10-12. SAGER, JK; GRIFFETH, RW \& HOM, PW 1998: A Comparison of Structural Models Representing Turnover Cognitions. Journal of Vocational Behaviour, 53(2):254-273.

SALOPEK, JJ \& DIXON, NM 2002: Common knowledge: How companies thrive by sharing what they know. Training \& Development, 54(4):63-64.

SCHEPERS, JM 2004: Overcoming the effects of differential skewness of test items in scale construction, SA Journal of Industrial Psychology, 30(4):27-43.

SCHEPERS, JM 1992: Toetskonstruksie: Teorie en praktyk. Johannesburg: RAU Drukpers.

SHIELDS, MA \& WARD, M 2001: Improving nurse retention in the National Health Service in England: the impact of job satisfaction on intentions to quit. Journal of Health Economics, 20(5):677701.

SLATE, RN \& VOGEL, RE 1997: Participative management and correctional personnel: a study of the perceived atmosphere for participation in correctional decision making and its impact on employee stress and thoughts about quitting. Journal of Criminal Justice, 25(5):397-408.

SMETHERHAM, J \& LAURANCE, J 2003: UK poaching of SA nurses carries on despite ban. Cape Times, 13 May.

SMIT, M 2003: Die lampie brand al flouer. Die Burger, 30 January. SMITH, CA; ORGAN, DW \& NEAR JP 1983: Organizational Citizenship Behavior: Its nature and antecedents. Journal of Applied Psychology, 68(4):653-663.

STEEL, R \& OVALLE, N 1984: A review and meta-analysis of research on the relationship between behavioural intentions and employee turnover. Journal of Applied Psychology, 69(4):673686.

TEPECI, M \& BARTLETT, ALB 2002: The hospitality industry culture profile: A measure of individual values, organizational culture, and person-organization fit as predictors of job satisfaction and behavioral intentions. International Journal of Hospitality Management, 21(2):151-170.

VAN DER POST, WZ; DE CONING, TJ \& SMIT, EV 1997: An instrument to measure organisational culture. South African Journal of Business Management, 28(4):147-168.

VAN DYNE, L \& LEPINE, JA 1998: Helping and voice extra-role behaviors: Evidence of construct and predictive validity. Academy of Management Journal, 41(1):108-120.

VUJICIC, M; ZURN, P; DIALLO, K; ADAMS, O \& DAL POZ, MR 2004: The role of wages in the migration of health care professionals form developing countries. Human Resources for Health. Available from http://www.human-resources-health.com/content/2/1/3 (Accessed 19 October 2004).

WAGNER, C; CASSIMJEE, N \& NEL, H 2002: Some key principles in implementing knowledge management: the views of employees in a small software company. SA Journal of Industrial Psychology, 28(2):49-54.

WELMAN, JC \& KRUGER, SJ 1999: Research methodology for the business and administrative sciences. Halfway House: Thomson International.

YANG, JT \& WAN, CS 2004: Advancing organizational effectiveness and knowledge management implementation. Management Accounting Research, 15(1):53-76. 


\section{ANNEXURE A: TURNOVER INTENTIONS QUESTIONNAIRE}

The following questionnaire measures your intentions to quit.

\begin{tabular}{|c|c|c|c|c|}
\hline 1. & $\begin{array}{l}\text { How often have you considered } \\
\text { leaving your current job? }\end{array}$ & Never & 1----2----3-----4----5-----6----7 & Most of the times \\
\hline 2. & $\begin{array}{l}\text { How frequently do you scan news } \\
\text { papers for job opportunities? }\end{array}$ & Never & 1----2----3----4-----5----6----7 & Most of the times \\
\hline 3. & $\begin{array}{l}\text { To what extent is your current job } \\
\text { not addressing your important } \\
\text { personal needs? }\end{array}$ & To no extent & 1----2----3----4-----5----6----7 & To a large extent \\
\hline 4. & $\begin{array}{l}\text { How often are opportunities to } \\
\text { achieve your most important goals } \\
\text { at work jeopardised? }\end{array}$ & Never & 1----2----3----4-----5----6----7 & Always \\
\hline 5. & $\begin{array}{l}\text { How often are your most important } \\
\text { personal values at work } \\
\text { compromised? }\end{array}$ & Never & 1----2-----3----4-----5----6-----7 & Always \\
\hline 6. & $\begin{array}{l}\text { How frequently are you day- } \\
\text { dreaming about a different job that } \\
\text { will suit your personal needs? }\end{array}$ & Never & 1----2----3-----4----5-----6----7 & Always \\
\hline 7. & $\begin{array}{l}\text { What is the probability that you will } \\
\text { leave your job, if you get another } \\
\text { suitable offer? }\end{array}$ & Low & 1----2-----3----4-----5----6----7 & High \\
\hline 8. & $\begin{array}{l}\text { How frequently do you look forward } \\
\text { to another day at work? }\end{array}$ & Always & 1----2----3----4-----5----6----7 & Never \\
\hline 9. & $\begin{array}{l}\text { How often do you think about } \\
\text { starting your own business? }\end{array}$ & Never & 1----2----3----4----5----6----7 & Most of the times \\
\hline 10. & $\begin{array}{l}\text { How often do only family } \\
\text { responsibilities preventing you from } \\
\text { quitting? }\end{array}$ & Never & 1----2-----3----4-----5----6----7 & Always \\
\hline 11. & $\begin{array}{l}\text { How often do only vested personal } \\
\text { interest fund, } \\
\text { unemployment fund, etc.) prevent } \\
\text { you from quitting? }\end{array}$ & Never & 1----2-----3----4-----5----6----7 & Always \\
\hline 12. & $\begin{array}{l}\text { How frequently are you emotionally } \\
\text { agitated when arriving home after } \\
\text { work? }\end{array}$ & Never & 1----2-----3----4-----5----6----7 & Always \\
\hline 13. & $\begin{array}{l}\text { How often is your current job } \\
\text { affecting on your personal well- } \\
\text { being? }\end{array}$ & Never & 1----2----3-----4----5----6-----7 & Always \\
\hline 14. & $\begin{array}{l}\text { How often do the troubles } \\
\text { associated with relocating, prevent } \\
\text { you from quitting? }\end{array}$ & Never & 1----2-----3----4----5-----6----7 & Always \\
\hline
\end{tabular}




\section{ANNEXURE B: KNOWLEDGE SHARING QUESTIONNAIRE}

The following questionnaire measures your perceptions about knowledge sharing in your organisation.

To what extent do you share knowledge in this organisation ...

\begin{tabular}{|l|l|l|l|l|l|l|l|}
\hline 1. to get recognition? & To no extent & 1 & 2 & 3 & 4 & 5 & To a large extent \\
\hline $\begin{array}{l}\text { 2. to be rewarded? } \\
\text { To no extent }\end{array}$ & 1 & 2 & 3 & 4 & 5 & To a large extent \\
\hline $\begin{array}{l}\text { 3. to satisfy your self-fulfillment } \\
\text { needs? }\end{array}$ & To no extent & 1 & 2 & 3 & 4 & 5 & To a large extent \\
\hline $\begin{array}{l}\text { 4. to support management } \\
\text { strategic objectives? }\end{array}$ & To no extent & 1 & 2 & 3 & 4 & 5 & To a large extent \\
\hline 5. to enhance your career? & To no extent & 1 & 2 & 3 & 4 & 5 & To a large extent \\
\hline
\end{tabular}

How often do you have the opportunity ...

\begin{tabular}{|l|l|l|l|l|l|l|l|}
\hline 6. to attend training courses? & Never & 1 & 2 & 3 & 4 & 5 & Most of the times \\
\hline $\begin{array}{l}\text { 7. to share your knowledge with } \\
\text { colleagues? }\end{array}$ & Never & 1 & 2 & 3 & 4 & 5 & Most of the times \\
\hline $\begin{array}{l}\text { 8. to attend informal gatherings } \\
\text { where knowledge is shared? }\end{array}$ & Never & 1 & 2 & 3 & 4 & 5 & Most of the times \\
\hline
\end{tabular}

How much do you agree that knowledge sharing contributes to...

\begin{tabular}{|l|l|l|l|l|l|l|l|}
\hline $\begin{array}{l}\text { 9. the success of this } \\
\text { organisation? }\end{array}$ & Disagree & 1 & 2 & 3 & 4 & 5 & Agree \\
\hline $\begin{array}{c}\text { 10. the competitiveness of this } \\
\text { organisation? }\end{array}$ & Disagree & 1 & 2 & 3 & 4 & 5 & Agree \\
\hline $\begin{array}{c}\text { 11. the innovativeness of this } \\
\text { organisation? }\end{array}$ & Disagree & 1 & 2 & 3 & 4 & 5 & Agree \\
\hline
\end{tabular}

To what extent do you experience that others share knowledge due to the following reasons...

\begin{tabular}{|l|l|l|l|l|l|l|l|}
\hline $\begin{array}{c}\text { 12. trust that exists in the } \\
\text { organisation? }\end{array}$ & To no extent & 1 & 2 & 3 & 4 & 5 & To a large extent \\
\hline $\begin{array}{c}\text { 13. the likelihood that colleagues } \\
\text { will do likewise? }\end{array}$ & To no extent & 1 & 2 & 3 & 4 & 5 & To a large extent \\
\hline $\begin{array}{c}\text { 14. it is highly valued by } \\
\text { management? }\end{array}$ & To no extent & 1 & 2 & 3 & 4 & 5 & To a large extent \\
\hline $\begin{array}{c}\text { 15. the organisational culture } \\
\text { facilitates a learning } \\
\text { environment? }\end{array}$ & To no extent & 1 & 2 & 3 & 4 & 5 & To a large extent \\
\hline $\begin{array}{c}\text { 16. people who share knowledge } \\
\text { are regarded as experts? }\end{array}$ & To no extent & 1 & 2 & 3 & 4 & 5 & To a large extent \\
\hline $\begin{array}{c}\text { 17. it contributes to positive } \\
\text { performance appraisals? }\end{array}$ & To no extent & 1 & 2 & 3 & 4 & 5 & To a large extent \\
\hline
\end{tabular}


To what extent you do not readily share knowledge due to the following reasons ...

\begin{tabular}{|c|c|c|c|c|c|c|c|}
\hline $\begin{array}{c}\text { 18. you are afraid your career } \\
\text { would be in danger if you } \\
\text { make mistakes?(-) }\end{array}$ & To no extent & 1 & 2 & 3 & 4 & 5 & To a large extent \\
\hline $\begin{array}{c}\text { 19. not enough trust exists in this } \\
\text { organisation? (-) }\end{array}$ & To no extent & 1 & 2 & 3 & 4 & 5 & To a large extent \\
\hline $\begin{array}{c}\text { 20. others don't want to do } \\
\text { likewise? (-) }\end{array}$ & To no extent & 1 & 2 & 3 & 4 & 5 & To a large extent \\
\hline
\end{tabular}

To what extent do you experience that others do not readily share knowledge due to the following reasons

\begin{tabular}{|c|c|c|c|c|c|c|c|}
\hline $\begin{array}{c}\text { 21. they are afraid their careers } \\
\text { would be in danger if they } \\
\text { make mistakes? (-) }\end{array}$ & To no extent & 1 & 2 & 3 & 4 & 5 & To a large extent \\
\hline $\begin{array}{c}\text { 22. not enough trust exist in this } \\
\text { organisation? (-) }\end{array}$ & To no extent & 1 & 2 & 3 & 4 & 5 & To a large extent \\
\hline $\begin{array}{c}\text { 23. colleagues don't want to do } \\
\text { likewise? (-) }\end{array}$ & To no extent & 1 & 2 & 3 & 4 & 5 & To a large extent \\
\hline
\end{tabular}

